\title{
Are Proterozoic cap carbonates and isotopic excursions a record of gas hydrate destabilization following Earth's coldest intervals?
}

\author{
Martin J. Kennedy Department of Earth Science, University of California, Riverside, California 92521, USA \\ Nicholas Christie-Blick \\ Linda E. Sohl \\ Lamont-Doherty Earth Observatory of Columbia University, Palisades, New York 10964, USA
}

\begin{abstract}
Regionally persistent, thin intervals of carbonate rock directly and ubiquitously overlie Proterozoic glacial deposits on almost every continent, and are commonly referred to as cap carbonates. Their unusual facies, stratigraphically abrupt basal and upper contacts, and strongly negative carbon isotopic signature $\left(\delta^{13} \mathrm{C}\right.$ values between $\sim 0 \%$ and $-5 \%$ o $)$ suggest a chemical oceanographic origin, the details of which remain unresolved. Here we propose that these enigmatic deposits are related to the destabilization of gas hydrate in terrestrial permafrost following rapid postglacial warming and flooding of widely exposed continental shelves and interior basins. Supporting evidence for this hypothesis includes (1) the common occurrence within the cap carbonates of unusual fabrics, similar to those produced by cold methane seeps; (2) a distinctive time evolution for the carbon isotopic excursions indicative of a pulse addition of isotopically depleted carbon to the oceanatmosphere system; and (3) agreement between mass-balance estimates of carbon released by hydrate destabilization and carbon buried in the cap carbonate. We infer that during times of low-latitude glaciation, characteristic of the Neoproterozoic, gas hydrates may have been in greater abundance than at any other time in Earth history.
\end{abstract}

Keywords: Neoproterozoic, methane, paleoclimate, glaciation, carbonate rocks.

\section{INTRODUCTION}

Abrupt carbon isotopic excursions that are present sporadically in marine carbonate rocks throughout the geological record provide evidence for significant disruption of the steadystate cycling of dissolved inorganic carbon (DIC) in the ocean. The most pronounced negative excursions $\left(\delta^{13} \mathrm{C}\right.$ values as low as $-5 \%$ ) are those observed in thin $(<5 \mathrm{~m})$, regionally persistent layers of carbonate rock that in many places directly overlie glacial deposits of Neoproterozoic age (Kaufman et al., 1997; Kennedy et al., 1998). The extreme isotopic depletion of these cap carbonates is matched by the unusual severity of Neoproterozoic glaciation; continental ice sheets extended at sea level to within a few degrees of the equator (Sohl et al., 1999). The distinctive isotopic signature of cap carbonates and their common presence as the only carbonate phase in otherwise siliciclastic successions has reinforced the view that these layers also have short-lived paleoenvironmental, chemical, oceanographic, and temporal significance (Knoll et al., 1986; Kaufman et al., 1993; Grotzinger and Knoll, 1995; Kennedy, 1996; Hoffman et al., 1998).

Proposed models for cap carbonate formation are of two classes. In one class of models, physical stratification produces a strong surface to deep carbon isotopic gradient in the ocean (Knoll et al., 1986; Kaufman et al., 1993, 1997; Grotzinger and Knoll, 1995). Postglacial upwelling delivers both alkalinity and isotopically light carbon to continental shelves and flooded interior basins, resulting in massive precipitation of inorganic carbonate. Possible weaknesses of such models include (1) the physical difficulty of stratifying the glacial ocean prior to cap carbonate deposition; (2) the positive (counter) effect on surface-marine carbonate-carbon isotopic values that enhanced upwelling of nutrient-rich deep water and associated productivity would have engendered; and (3) the expectation that carbon isotopic trends in the cap carbonates would be regionally and globally more variable than observed.

A second class of models calls upon a short-lived change in the carbon isotopic composition of the entire ocean. In the "snowball model" of Hoffman et al. (1998), this occurs when the surface ocean is covered by a nearly continuous carapace of sea ice that partitions the ocean and atmospheric $\mathrm{CO}_{2}$ reservoirs. A strong albedo feedback and diminished silicate weathering permit atmospheric $\mathrm{CO}_{2}$ to build up to levels as high as $\sim 120000 \mathrm{ppm}$ (for contrast, the value in today's atmosphere is $\sim 366 \mathrm{ppm}$ ) before triggering rapid deglaciation and melting of sea ice. Enhanced weathering then draws down $\mathrm{CO}_{2}$, delivering excess alkalinity to the ocean, and precipitating the cap carbonate. The main difficulties with the snowball model relate to the implausibility of a frozen tropical ocean under such high levels of atmospheric $\mathrm{CO}_{2}$ (Chandler and Sohl, 2000; Hyde et al., 2000), and to the high rates of silicate weathering required to draw down $\mathrm{CO}_{2}$ in the short interval of cap carbonate deposition. Because silicate weathering is the principal transfer mechanism of atmospheric $\mathrm{CO}_{2}$ to the sedimentary reservoir, and (according to the snowball model) a cap carbonate is the physical record of that transfer, weathering rates during deposition of a cap carbonate must be rapid enough to balance the latent weathering that did not occur during glacial time. Hoffman et al. (1998) estimated the glaciation and buildup of $\mathrm{CO}_{2}$ to have lasted $\sim 10^{7} \mathrm{yr}$, while the best estimates for the duration of cap carbonate deposition are $10^{3}$ $10^{4}$ yr (Kennedy, 1994; Hoffman et al., 1998; see following), requiring postglacial weathering rates to have been 3-4 orders of magnitude greater than those preceding the $\mathrm{CO}_{2}$ buildup. Yet $\mathrm{Sr}$ isotopic values through this interval provide no support for greatly diminished weathering during glaciation or for greatly enhanced weathering in its immediate aftermath (Kennedy et al., 1998; Jacobsen and Kaufman, 1999).

Here we consider an alternative hypothesis. Like the snowball model, it involves shortlived changes in the bulk carbon isotopic composition of the ocean, but it avoids some of the obvious difficulties associated with huge changes in atmospheric $\mathrm{CO}_{2}$. We suggest that the observed negative carbon isotopic excursion in cap carbonates may be due to the destabilization of gas hydrates in terrestrial permafrost as a result of postglacial warming and marine transgression.

\section{ORIGIN AND GEOCHEMICAL CONSEQUENCES OF CHANGES IN THE GAS HYDRATE BUDGET}

Gas hydrates are naturally occurring icelike substances composed of water and hydrocarbon gases, mainly methane (Kvenvolden, 1998). Methane, which is produced by the biogenic or thermogenic degradation of shallow to deeply buried organic-rich sediment, becomes sequestered as hydrate in regions of low surface temperature, particularly in terrestrial permafrost (at depths $>150 \mathrm{~m}$ ) and along the slopes and rises of continental margins (at water depths $>300 \mathrm{~m}$ ). Estimates of the amount of methane carbon in gas hydrates are understandably uncertain, but in the realm of $10^{4} \mathrm{Gt}$ (Kvenvolden, 1998), making gas hydrates roughly three times larger than the combined reactive carbon pools within the oceanatmosphere-terrestrial system.

Given the greater area available for terres- 

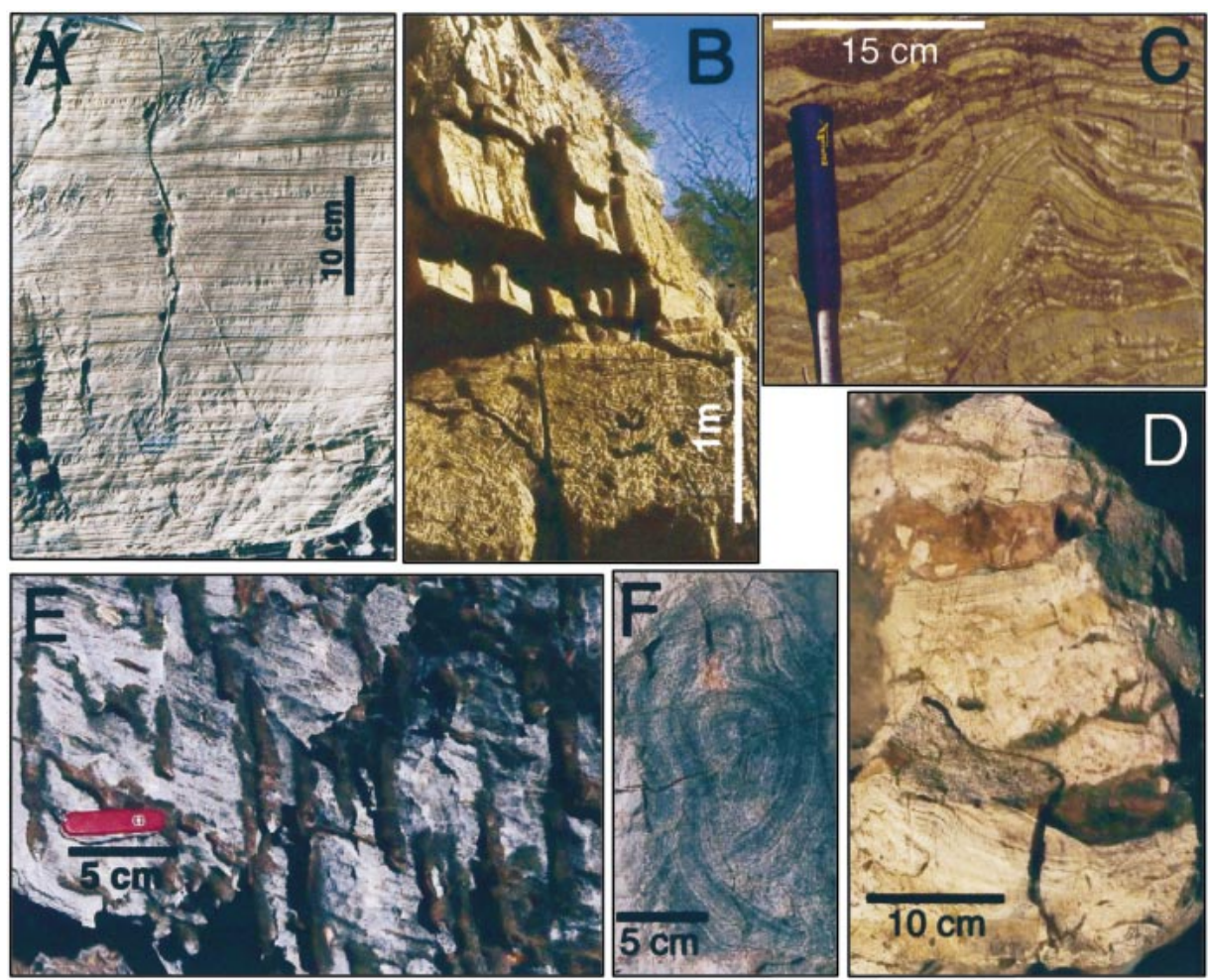

Figure 1. Cap carbonate lithofacies: A: Typical laminated dolomicrite. B: Facies with domal and tepee-shaped structures and abundant cement, overlain by laminated dolomite. C: Detail of B showing growth of tepee-shaped structure and sheet cracks lined by isopachous cement. D: Brecciation in core of structure, related to repeated bedding disruption and cementation. E: Tubestone facies, attributed to outgassing of methane. F: Roll-up structure, interpreted to represent microbial binding by chemosynthetic and/or heterotrophic organisms in deep water. All examples are from northern Namibia, except $D$ (Kimberley region, Australia).

trial permafrost accumulation in the broad intracratonic basins characteristic of the Neoproterozoic, and that oceanic temperatures would have been unusually cold at all latitudes during times of low-latitude glaciation, we infer that gas hydrates may have been in greater abundance during Neoproterozoic ice ages than at any other time in Earth history. Terrestrial permafrost, which accounts for only $\sim 0.2 \%-1 \%$ of today's gas hydrate inventory, would have been disproportionately more abundant (perhaps by a factor of $\geq 100$; see following).

Permafrost gas hydrate would have been sensitive to the significant warming accompanying postglacial transgression, and less sensitive than marine gas hydrates to the trade-off between increasing temperature and rising pressure (increasing water depth), which tends to stabilize marine hydrates (Paull et al., 1991; Kvenvolden, 1998). Methane release from flooded permafrost does not occur catastrophically because it requires temperature changes at Earth's surface to propagate downward to depths of hundreds of meters. This likely occurs on time scales of $10^{3}-10^{4}$ years, based on modern methane fluxes from offshore permafrost hydrates flooded after the last glacial stage (Kvenvolden, 1998).

As is the case at modern methane seeps, the bulk of the methane would have been oxidized by sulfate reduction within anoxic sediment near the seafloor and (to a lesser extent) within locally oxygen-depleted seawater (Aharon and Fu, 2000; Boetius et al., 2000). Sulfate reduction at seeps is facilitated by a microbial consortium that produces alkalinity enriched in ${ }^{12} \mathrm{C}$ as a reaction product (Boetius et al., 2000). Alkalinity produced by sulfate reduction of methane enhances carbonate deposition, in contrast to $\mathrm{pH}$ lowering and dissolution of carbonate, which occurs when methane is oxidized to $\mathrm{CO}_{2}$ in the ocean and atmosphere (Dickens et al., 1995). In the former case, significant sulfate reduction of methane should be reflected in the marine $\delta^{34} S$ record. The latter case may be more typical of the massive, short-lived gas hydrate destabilization and methane release that is sometimes induced by slumping. In either case, addition to the ocean of sufficient $\mathrm{CH}_{4}$ to drive a substantial negative carbon isotopic excursion must be balanced by an equivalent amount of carbon redeposited in a sedimentary reservoir either as biomass or carbonate.

Hypothesized changes in the gas hydrate pool are attractive because they are potentially capable of producing substantial shifts in the carbon isotopic composition of the ocean. Biogenic methane is isotopically highly de- pleted $\left(\delta^{13} \mathrm{C}\right.$ values between $-95 \%$ and $-60 \%$ ), whereas the isotopic composition of DIC in the ocean is typically close to $0 \%$. Destabilization of gas hydrate leads to a distinctive temporal isotopic evolution in the ocean that can be compared with the stratigraphic record (Dickens et al., 1995). We anticipate that methane would have been released as a pulse addition during climatic amelioration over a span of $10^{3}-10^{4} \mathrm{yr}$. Once conditions had stabilized, recovery of the ocean to normal isotopic values would have occurred over a longer interval $\left(\sim 10^{5} \mathrm{yr}\right)$ as the isotopically depleted stock of carbon was replaced by riverine input over several residence times (Kump, 1991).

\section{PHYSICAL RECORD OF GAS HYDRATE}

The physical record of gas hydrate is necessarily indirect. However, the destabilization of hydrate leads to methane seepage at the seafloor, a process that has been documented in both the modern environment with submersibles and in the geological record (Gaillard et al., 1992; von Bitter et al., 1992; Kauffman et al., 1996; Bohrmann et al., 1998). The introduction of methane into impermeable sediments results in the layer-parallel splitting, doming, and brecciation of beds by buoyant deformation from methane gas or displacive growth of secondary hydrate (e.g., Bohrmann et al., 1998). An increase in alkalinity related to sulfate reduction leads to the precipitation of isopachous marine cements in cavities and sheet cracks. The precipitation of carbonate also produces topographic features on the seafloor with as much as several meters of relief (Kauffman et al., 1996; Bohrmann et al., 1998). These seep-related carbonates have $\delta^{13} \mathrm{C}$ values of between $-60 \%$ and $+13 \%$, reflecting a range of metabolic pathways and mixing with seawater alkalinity (Gaillard et al., 1992; Kauffman et al., 1996). Active seeps are also associated with chemosynthetic communities, which utilize methane as an energy source. Their physical record includes a distinctive assemblage of microbial mats (Kauffman et al., 1996; Bohrmann et al., 1998), fossil tubes or pipes (Hovland, 1992; von Bitter et al., 1992), biohermal accumulations, encrusting cements, and upward-radiating crystal fans commonly composed of aragonite (Gaillard et al., 1992; von Bitter et al., 1992; Kauffman et al., 1996). This assemblage of physical and biological features is particularly distinctive in relatively low energy deep-water environments (below the photic zone), where most cold seep communities have been recognized.

\section{NEOPROTEROZOIC \\ CAP CARBONATES}

Cap carbonates are typically thin $(<2 \mathrm{~m})$, relatively homogeneous, finely laminated, and 
A

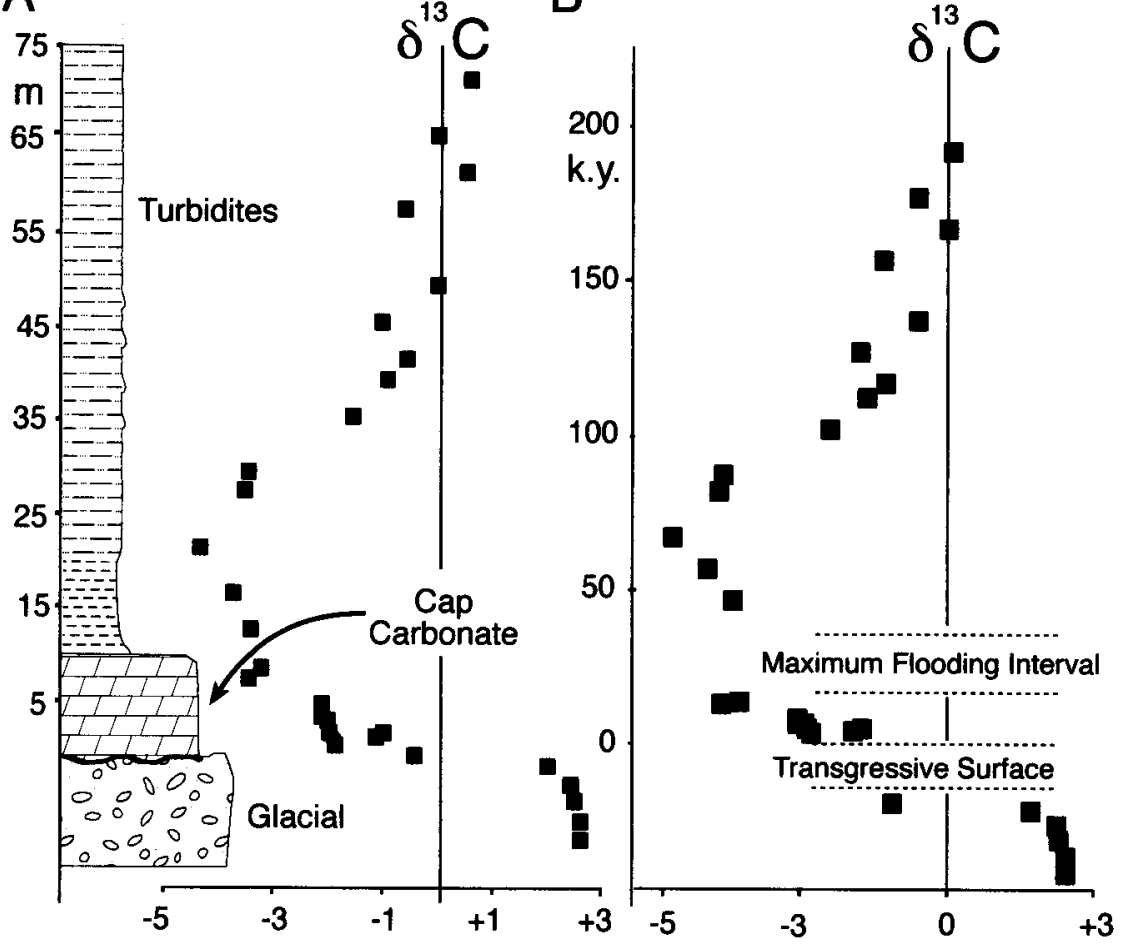

Figure 2. Carbon isotopic data from Maieberg Formation, Duurwater, northern Namibia (from Kennedy et al., 1998), plotted against stratigraphic position (A) and interpretation of time (B). Glacial values are derived from bedded dolomicrite, marine cement, and diamictite matrix beneath cap carbonate. Sediment accumulation rates assumed in B are $10 \mathrm{~cm} / \mathrm{k} . y$. for cap carbonate and $25 \mathrm{~cm} / \mathrm{k}$.y. for overlying upwardshoaling turbidite succession. These are appropriate for this sedimentary setting. Time model includes inferred hiatus within maximum flooding interval, shown here diagrammatically as 20 k.y.

composed primarily of microcrystalline dolomicrite (Fig. 1A). The carbonates overlie terrestrial and marine glacial and glacially related deposits with sharp, and in places erosional, contact. Upper boundaries are condensed or slightly gradational, with diagenetically modified nodular or cemented carbonate layers thinning upward into overlying shales. These shales then coarsen upward over as much as several hundred meters into siltstones with increasingly abundant sandstone (or carbonate) event layers. These observations suggest that cap carbonates accumulated in relatively deep water (to hundreds of meters), and record postglacial sea-level rise and transgression, followed by renewed shoaling (Kennedy, 1996).

\section{Anomalous Cap Facies}

Cap carbonates consistently include two other highly distinctive and enigmatic facies that until now have defied satisfactory explanation, but are reminiscent of features observed at methane seeps. While these facies are spatially discontinuous, they are present within cap carbonate units globally (Kennedy et al., 1998).

The first facies, characterized by abundant bedding expansion and cementation, is localized at the base of cap intervals. Regions of sheet cracks commonly pass laterally into domal or tepee-shaped structures (Fig. 1, BD). In places, bedding disruption is extreme, resulting in brecciation. Multiple generations of isopachous fringing cements, with internal sediments draping crystal terminations, fill cavities formed by bedding expansion. Lateral thinning and onlap of overlying layers indicate a protracted history for the development and burial of seafloor relief. The origin of the domical features is especially puzzling because their circular footprint in undeformed examples and incremental development during sedimentation precludes such mechanisms as slumping and tectonic deformation. However, such features are common in modern and ancient cold seep deposits.

The second facies is microbially laminated, with abundant tube-like structures (Fig. 1, E and F). Laterally discontinuous biohermal domes composed of diffusely laminated dolomicrite (cryptomicrobialite) are in places tens of meters thick (Hegenberger, 1987; Hoffman et al., 1998). Some finely laminated carbonate rocks contain roll-up structures and steeply overhanging meter-scale domes. These features and the presence of clotted textures suggest cohesion, most likely by mucilaginous microbial membranes (Kennedy, 1996; Hoffman et al., 1998). No evidence of subaerial exposure, fenestral fabrics, evaporites, or in- fluence by waves is present within the biohermal domes, which are laterally continuous with hemipelagic facies, thereby supporting a sub-storm-wave-base interpretation. Some examples are rich in pyrite and fetid, suggesting anoxic conditions. Associated with the domes are vertical spar-filled tubes, typically $1-3 \mathrm{~cm}$ in diameter and as much as several meters in length. In places, ghost laminae pass unbroken and undeformed through individual tubes. The tubestone has been variously interpreted as the result of gas or fluid escape (Hegenberger, 1987). The limited disruption within some tubes favors an origin involving gas, rather than liquid escape. The length of tubes $(>2 \mathrm{~m})$ suggests rapid deposition of the host sediment, with limited lithification. Formerly aragonitic and barite crystal fans spatially associated with biohermal domes are well developed in limited areas, and grew on the seafloor (Hegenberger, 1987; Kennedy, 1996; Hoffman et al., 1998). The spatial association of microbial and cemented facies further serves to strengthen the cold seep interpretation.

\section{Relation of Cap Carbonates to Carbon Isotope Excursions}

Carbon isotope values in cap carbonates globally range from $\sim 0 \%$ to $-5 \%$ o (Kaufman et al., 1997; Kennedy et al., 1998). The relation of the cap carbonates to the carbon isotope excursions with which they are associated is well defined in only a few sectionsthose in which sufficient carbonate is present above the cap level to define the entire excursion (e.g., Hoffman et al., 1998; Kennedy et al., 1998). Data from the southern margin of the Congo craton indicate that the excursion is strongly asymmetrical (Fig. 2), attaining minimum values within the transgressive portion of the stratigraphy. In the section illustrated, $\delta^{13} \mathrm{C}$ values begin at $-0.3 \%$, at the base of the cap carbonate, and reach a minimum $(-3.3 \%)$ in the middle of the cap carbonate $(2 \mathrm{~m})$ before rising to $1.1 \%$ o in turbidite grainstones $\sim 41 \mathrm{~m}$ upsection (Kennedy et al., 1998).

\section{Time-Scale Considerations}

High-resolution stratigraphic mapping in a transect across the margin of the Amadeus basin of central Australia provides indirect clues about the time scale represented by cap carbonates, and a rare glimpse of shallow-water time-equivalent facies. The cap carbonate that overlies the younger Neoproterozoic (Marinoan) glacial deposits in that area passes laterally and abruptly into an unusually coarse grained assemblage of nearshore and nonmarine sandstone and conglomerate $<200 \mathrm{~m}$ thick (Kennedy, 1994). The succession is divisible into four unconformity-related sequences, each strongly asymmetrical and transgressive dominated, and together repre- 
senting only a portion of the late glacial to postglacial transgression. The cap carbonate represents a small fraction of a single sequence and, by analogy with the late Cenozoic, is inferred to represent a time scale of $10^{3}-10^{4}$ yr. These stratigraphic relationships support the idea that the negative carbon isotopic shift developed abruptly. Scaling considerations suggest that the recovery of isotopic values required an interval of $10^{5} \mathrm{yr}$ (Fig. 2B).

\section{Isotopic and Carbon Mass Balance}

At a global scale, methane release plausibly accounts for the $-5 \%$ carbon isotopic excursions preserved at least twice in the Neoproterozoic record. Complementary $\delta^{34} \mathrm{~S}$ excursions in Neoproterozoic postglacial sulfides (Ross et al., 1995) and trace sulfate in carbonate (Hurtgen et al., 2000) are consistent with the hypothesis that excess methane was oxidized by sulfate, and produced the alkalinity that is preserved in the cap carbonates. Assuming the modern DIC amount $\left(10^{4} \mathrm{Gt}\right)$ and carbon isotopic composition (0\%o) for the ocean, and that the isotopic composition of the methane released was $-60 \%$, the minimum amount of methane required is estimated as 3 $\times 10^{17}$ moles of $\mathrm{CH}_{4}$.

A carbon budget based on an estimate of the cap carbonate mass, assuming a 1-m-thick layer with an areal extent comparable to that of modern continental shelves $\left(2.7 \times 10^{7}\right.$ $\mathrm{km}^{2}$ ), provides $8 \times 10^{17}$ moles of carbonate. Thus the amount of $\mathrm{C}$ buried in the cap carbonate is roughly comparable to the isotopic mass-balance estimate of $\mathrm{C}$ released from methane. It is also comparable to an independent estimate of $7 \times 10^{17}$ moles of $\mathrm{CH}_{4}$ based on the methane flux from flooded hydrates on the Arctic shelf (Kvenvolden, 1998; and references therein) expanded to the modern shelf area. It is likely that the shelf area used in this calculation represents a minimum estimate of permafrost hydrate extent, given the potential additional area available in Neoproterozoic intracratonic basins and extension of permafrost conditions to equatorial latitudes. These estimates also do not include additional sources of methane from gas hydrates destabilized beneath retreating ice sheets or on upper continental slopes warmed by postglacial water (Kvenvolden, 1998).

In presenting this hypothesis, our intent is to stimulate new research. Given that cap carbonates and their associated isotopic excursions are limited to times in the Proterozoic during which conditions would have been highly favorable for gas hydrate formation, we pose a different question: How can consideration of changes in this pool of organic carbon be avoided?

\section{ACKNOWLEDGMENTS}

The research on which this paper is based was supported by National Science Foundation grants EAR-94-18294, EAR-96-14070, and ATM-9907640. We thank M.A. Arthur, L.A. Derry, G.R. Dickens, I.J. Fairchild, S.R. Hemming, S. Jensen, J. Lynch-Stieglitz, and K.A. Kvenvolden for helpful reviews and comments. Lamont-Doherty Earth Observatory Contribution 6151.

\section{REFERENCES CITED}

Aharon, P., and Fu, B., 2000, Microbial sulfate reduction rates and sulfur and oxygen isotope fractionations at oil and gas seeps in deep water Gulf of Mexico: Geochimica et Cosmochimica Acta, v. 64, p. 233-246.

Boetius, A., Ravenschlag, K., Schubert, C.J., Rickert, D., Widdel, F., Gieseke, A., Amann, R., Barker Jørgensen, B., Witte, U., and Pfannkuche, O., 2000, A marine microbial consortium apparently mediating anaerobic oxidation of methane: Nature, v. 407, p. 623-626.

Bohrmann, G., Greinert, J., Suess, E., and Torres, M., 1998, Authigenic carbonates from the Cascadia subduction zone and their relation to gas hydrate stability: Geology, v. 26, p. 647-650.

Chandler, M.A., and Sohl, L.E., 2000, Climate forcings and the initiation of low-latitude ice sheets during the Neoproterozoic Varanger glacial interval: Journal of Geophysical Research, v. 105, p. 20737-20756.

Dickens, G.R., O’Neil, J.R., Rea, D.K., and Owen, R.M., 1995, Dissociation of oceanic methane hydrate as a cause of the carbon isotope excursion at the end of the Paleocene: Paleoceanography, v. 10, p. 965-971.

Gaillard, C., Rio, M., Rolin, Y., and Roux, M., 1992, Fossil chemosynthetic communities related to vents or seeps in sedimentary basins: The pseudobioherms of southeastern France compared to other world examples: Palaios, v. 7 , p. $451-465$.

Grotzinger, J.P., and Knoll, A.H., 1995, Anomalous carbonate precipitates: Is the Precambrian the key to the Permian?: Palaios, v. 10, p. 578-596.

Hegenberger, W., 1987, Gas escape structures in Precambrian peritidal carbonate rocks: Geological Survey of South West Africa/Namibia Communications, v. 3, p. 49-55.

Hoffman, P.F., Kaufman, A.J., Halverson, G.P., and Schrag, D.P., 1998, A Neoproterozoic snowball Earth: Science, v. 281, p. 1342-1346.

Hovland, M., 1992, Hydrocarbon seeps in northern marine waters; their occurrence and effects: Palaios, v. 7, p. 376-382.

Hurtgen, M.T., Arthur, M.A., and Suits, N.S., 2000, The sulfur isotopic composition of Neoproterozoic seawater sulfate: Implications for a "Snowball Earth": Geological Society of America Abstracts with Programs, v. 32 , no. 7 , p. 375 .

Hyde, W.T., Crowley, T.J., Baum, S.K., and Peltier, W.R., 2000, Neoproterozoic 'snowball Earth' simulations with a coupled climate/ice-sheet model: Nature, v. 405, p. 425-429.

Jacobsen, S.B., and Kaufman, A.J., 1999, The Sr, C and $\mathrm{O}$ isotopic evolution of Neoproterozoic seawater: Chemical Geology, v. 161, p. 37-57.

Kauffman, E.G., Arthur, M.A., Howe, B., and Scholle, P.A., 1996, Widespread venting of methane-rich fluids in Late Cretaceous (Campanian) submarine springs (Tepee Buttes), Western Interior seaway, USA: Geology, v. 24, p. 799-802.

Kaufman, A.J., Jacobsen, S.B., and Knoll, A.H., 1993, The Vendian record of Sr and C isotopic variations in seawater: Implications for tectonics and paleoclimate: Earth and Planetary Science Letters, v. 120, p. 409-430.

Kaufman, A.J., Knoll, A.H., and Narbonne, G.M., 1997, Isotopes, ice ages, and terminal Proterozoic Earth history: National Academy of Sciences Proceedings, v. 94, p. 6600-6605.

Kennedy, M.J., 1994, The influence of diapirism and deglaciation on the development of the Neoproterozoic stratigraphy of the Amadeus basin, central Australia [Ph.D. thesis]: Adelaide, South Australia, University of Adelaide, $186 \mathrm{p}$.

Kennedy, M.J., 1996, Stratigraphy, sedimentology, and isotopic geochemistry of Australian Neoproterozoic postglacial cap dolostones: Deglaciation, $\delta^{13} \mathrm{C}$ excursions, and carbonate precipitation: Journal of Sedimentary Research, v. 66 , p. $1050-1064$.

Kennedy, M.J., Runnegar, B., Prave, A.R., Hoffmann, K.-H., and Arthur, M.A., 1998, Two or four Neoproterozoic glaciations?: Geology, v. 26 , p. $1059-1063$.

Knoll, A.H., Hayes, J.M., Kaufman, A.J., Swett, K., and Lambert, I.B., 1986, Secular variation in carbon isotope ratios from Upper Proterozoic successions of Svalbard and East Greenland: Nature, v. 321, p. 832-838.

Kump, L.R., 1991, Interpreting carbon-isotope excursions: Strangelove oceans: Geology, v. 19, p. 299-302.

Kvenvolden, K.A., 1998, A primer on the geological occurrence of gas hydrate, in Henriet, J.-P., and Mienert, J., eds., Gas hydrates: Relevance to world margin stability and climate change: Geological Society [London] Special Publication 137, p. 9-30.

Paull, C., Ussler, W., III, and Dillon, W., 1991, Is the extent of glaciation limited by marine gashydrates?: Geophysical Research Letters, v. 18, p. 432-434.

Ross, G.M., Bloch, J.D., and Krouse, H.R., 1995, Neoproterozoic strata of the southern Canadian Cordillera and the isotopic evolution of seawater sulfate: Precambrian Research, v. 73, p. 71-99.

Sohl, L.E., Christie-Blick, N., and Kent, D.V., 1999, Paleomagnetic polarity reversals in Marinoan (ca. $600 \mathrm{Ma}$ ) glacial deposits of Australia: Implications for the duration of low-latitude glaciation in Neoproterozoic time: Geological Society of America Bulletin, v. 111, p. 1120-1139.

von Bitter, P.H., Scott, S.D., and Schenk, P.E., 1992, Chemosynthesis: An alternate hypothesis for Carboniferous biotas in bryozoan/microbial mounds, Newfoundland, Canada: Palaios, v. 7 , p. $466-484$.

Manuscript received October 26, 2000

Revised manuscript received January 16, 2001

Manuscript accepted January 29, 2001

Printed in USA 